Journal of Zhejiang University SCIENCE A ISSN 1673-565X (Print); ISSN 1862-1775 (Online) www.zju.edu.cn/jzus; www.springerlink.com E-mail: jzus@zju.edu.cn

\title{
Editorial:
}

\section{SCI citation analysis and impact factor prediction of JZUS-A in 2008}

\author{
Zi-yang ZHAI, Xiu-fang WU, Yue-hong (Helen) ZHANG \\ (Editors, Journals of Zhejiang University SCIENCE (A\&B), Zhejiang University Press, Hangzhou 310027, China) \\ E-mail: jzus@zju.edu.cn
}

doi:10.1631/jzus.A0840002

Journal of Zhejiang University-SCIENCE A (JZUS-A), its former version named Journal of Zhejiang University-SCIENCE (ISSN 1009-3095), has been covered by Science Citation Index Expanded (SCI-E) since 2007. Till now, all the 500 papers published in JZUS-A during 2007 and 2008 have been abstracted and indexed into Web of Science.

In 2008, we have been striving to further improve the internationalization and the paper quality of JZUS-A. Our work mainly includes:

(1) We adopted Editorial Manager ${ }^{\mathrm{TM}}$ online submission system (http://www.editorialmanager. com/zusa/), which greatly advances the peer review process and also leads to an unexpected trust between the peer reviewers/authors and the journal.

(2) We joined in CrossCheck ${ }^{\mathrm{TM}}$ as the first member in China, which is a new anti-plagiarism tool released by CrossRef to verify and protect the originality and copyright of submitted manuscripts.

The year of 2008 is quite important for this journal. The papers published in this year will, together with those in 2007, be the source data to calculate the first impact factor (IF) of JZUS-A in 2009, which will be released in July 2010. In order to better understand our situation and deliver it to authors, readers and peer reviewers, since 2004 we have periodically performed a cited reference search within Web of Science for citations to documents published in the journal.

Fig.1 shows that the total citations of each year increased rapidly, especially from 2004 to 2008. Fig.2 shows that the articles published in 2004 2006 were most cited. Also we found that JZUS-A's articles were mainly cited by these journals, Composite Structures (21 citations), Lecture Notes in Computer Science (13 citations), Structural Engineering and Mechanics (8 citations), Microwave and Optical Technology Letters (8 citations), and Spectrochimica Acta Part A-Molecular and Biomolecular Spectroscopy (7 citations), etc.

Table 1 lists the most highly cited articles of JZUS-A during 2000 2008, showing a recent increase of citations to Electrical \& Electronic Engineering articles (Anon., 2007).

We refreshed our citation database weekly. According to the latest search performed on Dec. 13, 2008 , we obtain the current IF of 0.200 (114/569, the ratio of the number of citations received in 2008 by all documents published in JZUS-A in 2006 and 2007 to the total number of citable documents published in JZUS-A in 2006 and 2007). With the 4-week tracking method (Ketcham, 2007; Wu et al., 2008; Lin et al., 2009), we predict that the JZUS-A's 2008 IF falls in the range $0.222 \sim 0.274$ (averaged IF is 0.236 ), higher than the predicted 2007 IF, 0.159. As Journal Citation Reports (JCR) processing deadline is around mid-February following the JCR year, we can estimate the IF at least four months before its official release in June or July.

And also we analyzed that the non-self-citation and the self-citation rates related to the predicted JZUS-A's 2008 IF, are 73.7\% (84/114) and 26.3\% (30/114), respectively; the self-citation rate is in the normal range similar to that $(20 \% \sim 30 \%)$ of other newly SCI-covered journals at the same status.

Two major reasons can explain the recent uptrend of JZUS-A's IF: strict international peer review process and higher paper quality. Moreover, it is reasonable to anticipate a further increase in JZUS-A's 2009 IF. 


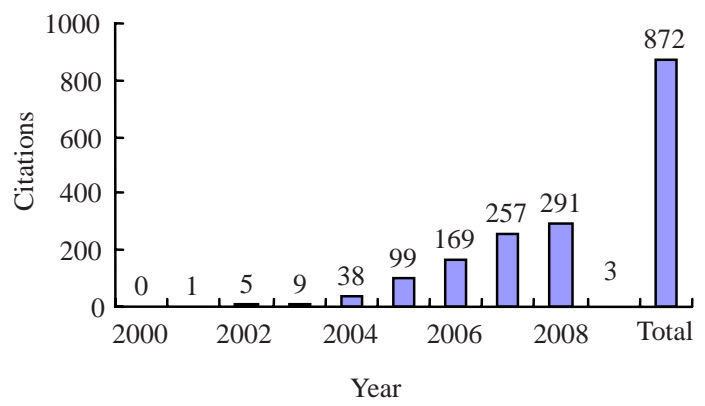

Fig.1 Annual SCI citation records of JZUS-A from 2000 to 2008 (up to Dec. 13, 2008)

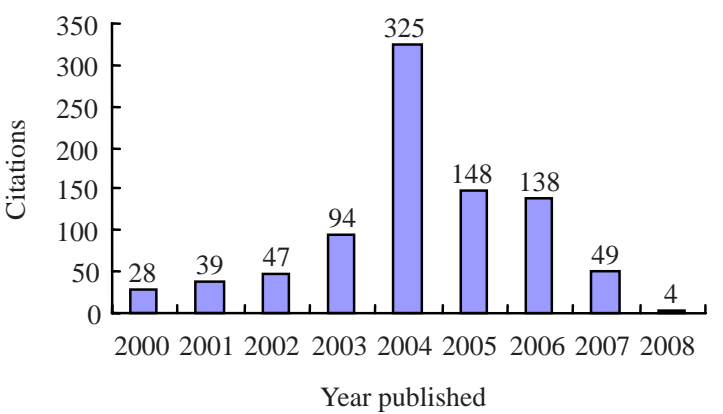

Fig.2 SCI citation records of annual JZUS-A articles from 2000 to 2008 (up to Dec. 13, 2008)

Table 1 The most highly cited articles in JZUS-A from 2000 to 2008 (up to Dec. 13, 2008)

\begin{tabular}{|c|c|c|c|c|}
\hline Citations & Author & Affiliation & Year, Vol.(No.):Page & Article title [doi] \\
\hline 16 & $\begin{array}{l}\text { SHEN J } \\
\text { et al. }\end{array}$ & $\begin{array}{l}\text { Zhejiang University, } \\
\text { China }\end{array}$ & 2004, 5(11):1322 & $\begin{array}{l}\text { How to realize a negative refractive index material at the atomic } \\
\text { level in an optical frequency range? } \\
\text { [doi:10.1631/jzus.2004.1322] }\end{array}$ \\
\hline 15 & $\begin{array}{l}\text { CHEN WQ } \\
\text { et al. }\end{array}$ & $\begin{array}{l}\text { Zhejiang University, } \\
\text { China }\end{array}$ & 2003, 4(1):1 & $\begin{array}{l}\text { Three-dimensional analysis of a thick FGM rectangular plate in } \\
\text { thermal environment [doi:10.1631/jzus.2003.0001] }\end{array}$ \\
\hline 13 & $\begin{array}{l}\text { HU WQ } \\
\text { et al. }\end{array}$ & $\begin{array}{l}\text { Zhejiang University, } \\
\text { China }\end{array}$ & 2000, 1(2):157 & $\begin{array}{l}\text { The polymerization of methyl methacrylate with a new Tin- } \\
\text { bridged yttrocene/Al(i-Bu })_{3} \text { [doi:10.1631/jzus.2000.0157] }\end{array}$ \\
\hline 12 & $\begin{array}{l}\text { Zhang LP } \\
\text { et al. }\end{array}$ & $\begin{array}{l}\text { Zhejiang University, } \\
\text { China }\end{array}$ & 2005, 6A(6):528 & $\begin{array}{l}\text { Optimal choice of parameters for particle swarm optimization } \\
\text { [doi:10.1631/jzus.2005.A0528] }\end{array}$ \\
\hline 10 & $\begin{array}{l}\text { CHEN P } \\
\text { et al. }\end{array}$ & $\begin{array}{l}\text { Zhejiang University, } \\
\text { China }\end{array}$ & 2001, 2(4):448 & $\begin{array}{l}\text { Changes of oxidative and lipoperoxidative metabolism in pa- } \\
\text { tients with acute viral myocarditis } \\
\text { [doi:10.1631/jzus.2001.0448] }\end{array}$ \\
\hline 8 & $\begin{array}{l}\text { QIAN H } \\
\text { et al. }\end{array}$ & $\begin{array}{l}\text { Southern Yangtze } \\
\text { University, China }\end{array}$ & 2004, 5(6):676 & $\begin{array}{l}\text { Antioxidant power of phytochemicals from Psidium guajava } \\
\text { leaf [doi:10.1631/jzus.2004.0676] }\end{array}$ \\
\hline 8 & $\begin{array}{l}\text { ZHANG CQ } \\
\text { et al. }\end{array}$ & $\begin{array}{l}\text { Zhejiang University, } \\
\text { China }\end{array}$ & 2004, 5(2):193 & $\begin{array}{l}\text { Effect of polychlorinated biphenyls on spermatogenesis and } \\
\text { testosterone secretion in adult cocks } \\
\text { [doi:10.1631/jzus.2004.0193] }\end{array}$ \\
\hline 8 & $\begin{array}{l}\text { ZHANG XW } \\
\text { et al. }\end{array}$ & $\begin{array}{l}\text { Zhejiang University, } \\
\text { China }\end{array}$ & 2004, 5(12):1548 & $\begin{array}{l}\text { Synthesis of } \mathrm{TiO}_{2} \text { supported on activated carbon by MOCVD: } \\
\text { operation parameters study [doi:10.1631/jzus.2004.1548] }\end{array}$ \\
\hline 7 & $\begin{array}{l}\text { HE GQ } \\
\text { et al. }\end{array}$ & $\begin{array}{l}\text { Zhejiang University, } \\
\text { China }\end{array}$ & 2004, 5(2):149 & $\begin{array}{l}\text { Improved elastase production by Bacillus sp. EL31410 - fur- } \\
\text { ther optimization and kinetics studies of culture medium for } \\
\text { batch fermentation [doi:10.1631/jzus.2004.0149] }\end{array}$ \\
\hline 7 & $\begin{array}{l}\text { TANG DS } \\
\text { et al. }\end{array}$ & $\begin{array}{l}\text { Zhejiang University, } \\
\text { China }\end{array}$ & 2004, 5(6):668 & $\begin{array}{l}\text { Interaction of catechins with aluminum in vitro } \\
\text { [doi:10.1631/jzus.2004.0668] }\end{array}$ \\
\hline 7 & $\begin{array}{l}\mathrm{XU} \text { YP } \\
\text { et al. }\end{array}$ & $\begin{array}{l}\text { Zhejiang University, } \\
\text { China }\end{array}$ & 2003, 4(4):491 & $\begin{array}{l}\text { Correlation of matrix metalloproteinase-2, }-9 \text {, tissue inhibitor-1 } \\
\text { of matrix metalloproteinase and CD } 44 \text { variant } 6 \text { in head and } \\
\text { neck cancer metastasis [doi:10.1631/jzus.2003.0491] }\end{array}$ \\
\hline 7 & $\begin{array}{l}\text { YE XJ } \\
\text { et al. }\end{array}$ & $\begin{array}{l}\text { Zhejiang University, } \\
\text { China }\end{array}$ & 2004, 5(2):226 & $\begin{array}{l}\text { Homoharringtonine induces apoptosis of endothelium and } \\
\text { down-regulates VEGF expression of K562 cells } \\
\text { [doi:10.1631/jzus.2004.0226] }\end{array}$ \\
\hline 7 & $\begin{array}{l}\text { CHEN AL } \\
\text { et al. }\end{array}$ & $\begin{array}{l}\text { Shanghai Jiao Tong } \\
\text { University, China }\end{array}$ & 2006, 7(4):607 & $\begin{array}{l}\text { Hybrid discrete particle swarm optimization algorithm for ca- } \\
\text { pacitated vehicle routing problem } \\
\text { [doi:10.1631/jzus.2006.A0607] }\end{array}$ \\
\hline
\end{tabular}

\section{References}

Anon., 2007. Analysis on uptrend JZUS (A\&B) SCI citation records and DOI resolutions. J. Zhejiang Univ. Sci. A, 8(12):i-ii.

Ketcham, C.M., 2007. Predicting impact factor one year in advance. Laboratory Investigation, 87:520-526. [doi:10. 1038/labinvest.3700554]
Lin, H.F., Wu, X.F., Zhang, Y.H., 2009. SCI citation analysis and impact factor prediction of JZUS-B in 2008. $J$. Zhejiang Univ. Sci. B, 10(1):77-78. [doi:10.1631/jzus. B0840002]

Wu, X.F., Fu, Q., Rousseau, R., 2008. On indexing in the Web of Science and predicting journal impact factor. $J$. Zhejiang Univ. Sci. B, 9(7):582-590. [doi:10.1631/jzus. B0840001] 